\title{
Social work, queer theory and after: A genealogy of sexuality theory in neoliberal times
}

DOI:

10.1093/bjsw/bcw103

\section{Document Version}

Accepted author manuscript

Link to publication record in Manchester Research Explorer

\section{Citation for published version (APA):}

Hicks, S., \& Jeyasingham, D. (2016). Social work, queer theory and after: A genealogy of sexuality theory in neoliberal times. The British Journal of Social Work, [1-17]. https://doi.org/10.1093/bjsw/bcw103

\section{Published in:}

The British Journal of Social Work

\section{Citing this paper}

Please note that where the full-text provided on Manchester Research Explorer is the Author Accepted Manuscript or Proof version this may differ from the final Published version. If citing, it is advised that you check and use the publisher's definitive version.

\section{General rights}

Copyright and moral rights for the publications made accessible in the Research Explorer are retained by the authors and/or other copyright owners and it is a condition of accessing publications that users recognise and abide by the legal requirements associated with these rights.

\section{Takedown policy}

If you believe that this document breaches copyright please refer to the University of Manchester's Takedown Procedures [http://man.ac.uk/04Y6Bo] or contact uml.scholarlycommunications@manchester.ac.uk providing relevant details, so we can investigate your claim.

\section{OPEN ACCESS}




\title{
Social work, queer theory and after: A genealogy of sexuality theory in neoliberal times
}

\begin{abstract}
This article presents a genealogy of social work approaches to sexuality via critical examination of the relevance of queer and post-queer theory. The key tenets of queer theory are outlined before the authors go on to assess how social work has responded to this body of work. The authors offer some critical comments on social work's engagement with queer theory before moving on to discuss a range of post-queer developments, focused on race, empire, the neoliberal state, class, austerity, gender and anti-normativity. As social work has yet to engage with post-queer theory, the authors assess some of its key contributions and, finally, discuss their suggestions for ways in which this literature might offer opportunities for the reinvigoration of research, theory and practice in the contemporary field of social work and sexuality.
\end{abstract}

Keywords: LGBT people; Anti-oppressive practice; Sexuality; Social work theory; Queer theory; Post-queer theory.

Subject categories: People, groups and communities: Gender issues; LGBT people; Race and racism; Social work and social workers: Social work theories.

This is an author accepted version of a manuscript published in British Journal of Social Work (2016). Copyright Oxford University Press. 


\section{Social work, queer theory and after: A genealogy of sexuality theory in neoliberal times}

A genealogy of social work and sexuality theory might consider a range of contemporary approaches to the subject: radical social work, gay-affirmative theory, anti-discriminatory practice, cultural competence, intersectionality theory, and so on. However, in this article we turn our attention to queer and post-queer theories, since social work's engagement with these has been minimal although, in some cases, growing. We do this because we think that these perspectives have much to offer the social work discipline, not least because they provide us with tools to challenge neoliberal regimes and their strangulating effects on social welfare.

We begin by considering some of the texts now regarded as foundational to queer theory, as well as outlining some of queer's key tenets, moving on, in the second section, to assess how far social work has engaged with these. Having done this, we then turn to post-queer theory, developments which we think will be less familiar to social work and our readers. By 'post-queer', we do not mean those perspectives that reject queer theory, proclaiming its demise - although these do exist (Ruffolo, 2009; Penney, 2014) - rather, we refer to a range of developments which push queer theory in new and exciting directions. Given the wide range of post-queer writing, our discussion is, inevitably, selective and has been guided by our thinking about what might be most us eful and accessible for social work. Some of our omissions, such as work on affect generally, shame in particular, queer's anti-social turn and a range of utopian oriented writing, are clearly relevant but require more explanation than 
is possible here. Rather, we assess post-queer developments concerning race, empire, the neoliberal state, class, austerity, gender and anti-normativity, before, finally, considering their implications for a reinvigoration of social work theory.

\section{Queer theory's key arguments:}

New ways of thinking through sexuality:

In an essay commonly understood as a founding moment for queer theory, de Lauretis argues that the field known as lesbian and gay studies is largely silent on questions of race, gender and 'attendant differences of class or ethnic culture, generational, geographical, and socio-political location' (de Lauretis, 1991, pp.iii-iv). Her point is that these should not merely be added as an afterthought, rather they should be used 'to recast or reinvent the terms of our sexualities' (de Lauretis, 1991, p.iv). Thus, queer theory problematises the terms of lesbian and gay studies and opens up new forms of enquiry that, at first glance, appear to have little to do with sexuality, such as the care of older people, questions of nationalism or temporality. This problematisation also includes a second component, questioning the perceived limitations of liberal rights politics, wherein campaigns for equality, such as gay marriage, may actually reinforce conventional, state approved ways of living at the expense of others (Cohen, 1997; Duggan, 2003).

Alongside these measures, queer theory demonstrates a concern with language and sexuality as a form of knowledge. Influenced by Foucault's view of sexological discourses as both enabling and constraining, queer suggests that subjectivity is taken up within discourses that produce and delimit the possibilities for sexual identity. Foucault's argument 
that sexuality is 'the name that can be given to a historical construct' (Foucault, 1990, p.105) is adopted in order to argue that knowledge is a powerful producer of both meanings and subjectivities, and that these establish moral/sexual hierarchies. This has profound implications for queer theory, since Foucault objects to the notion of self as source and authenticator of meaning and identity, and instead suggests that the self is produced through emergence into discourse. Thus, Halperin argues that Foucault's thought encourages queer theory to regard sexuality both as the result of powerful practices of knowledge and as a 'site for the continuing construction and renewal of continually changing identities' (Halperin, 1995, p.122).

This concern with knowledge is also a central theme of Sedgwick's Epistemology of the Closet (1990), which argues that the homo/heterosexual distinction emerges as a structural, highly productive and morally loaded feature of Western culture. Sedgwick charts a range of binaries through which distinctions between hetero/homosexuality are made and endowed with meaning: secrecy/disclosure, knowledge/ignorance, health/illness, natural/artificial, discipline/terrorism, wholeness/decadence, domestic/foreign, and so on. Though the list is extensive, it is hardly complete because the question of homo/heterosexual definition holds the potential to inhabit all manner of uncertainties, with Sedgwick adding that any insight regarding sexuality is always, at the same time, structured by the 'privilege of unknowing' (Sedgwick, 1990, p.8).

Querying received notions of subjectivity/identity:

Queer is commonly framed as questioning identity as a basis for enquiry or politics, particularly calling into question received wisdom about gender and sexuality. For example, 
Sedgwick argues that, as homosexuality becomes knowable, then the closet - an opensecret structure - also develops as a way of encountering homos exuality without having to recognise it as such. Through this structure of knowing-but-not-knowing, apparently clear signs of homos exuality fail to count as meaningful. However, given the taboos against recognising or speaking about homosexuality, then it is always a possibility, so all kinds of things become potential signs of its concealed presence. In such contexts, the question of whether to speak of homosexuality or to keep it secret becomes overloaded with significance, so that doing either warrants retribution. But, even such retribution may be read as a further sign of possible homosexuality, as shown by Sedgwick's discussion of the use of 'homosexual panic' as a legal defence for violence against gay men in the late 1980s (Sedgwick, 1990, p.19).

Butler's Gender Trouble (1990) is concerned with the subversion of identity and makes the case that sexuality categories, while apparently natural, are contingent on female/male sex distinctions that emerge out of gendered discourse. Butler argues against unthinking attachment to such categories, and is particularly critical of some feminist theory's reliance on an essentialist notion of 'women', partly because such a notion is already gendered there is no sex outside gender - but also because the act of presenting 'women' as universal has exclusionary effects in terms of gender, race and other dimensions. For Butler, sex has no substance; it seems to be internal to the body, but it is an illusion projected on to the body's surface, maintained through the persistent repetition of gendering acts or 'regulatory fictions' (Butler 1990, p.32). Genitals, for instance, are not indicators of the bodily fact of binary sexual difference, instead they come to symbolise sexual difference through systems of naming and categorisation. In making such arguments, Butler is 
exploring how sex appears to be a cause of social identities but is actually a product of discursive regimes that regulate experience.

\section{Performativity:}

Butler proposes that aspects of identity commonly treated as essential are actually performative; that is, they are achieved through the persistent and stylised repetition of acts. Race is not, therefore, an aspect of biologically distinct bodies, but a system of discipline through which subjects are formed and required to form themselves (Ehlers, 2012) and gender, too, is constantly produced through the repetition of 'bodily gestures, movements, and enactments of various kinds,' (Butler, 1988, p.519). And, if gender is constituted through various acts that are only arbitrarily related to one another, then it can also be subverted through a different kind of repetition. For example, in Gender Trouble, Butler argues that heterosexuality must be repeatedly cited and, in this sense, is only ever a parody of the idea of the natural/original. Practices such as drag highlight the illusory nature of gender and, in imitating supposedly original or natural gender categories, drag actually exposes 'the imitative structure of gender itself - as well as its contingency' (Butler, 1990, p.137).

Theorising sexual normativity:

In 'Thinking Sex', Rubin suggests that sexual acts and persons are subject to hierarchical appraisal, in which a 'charmed circle', largely 'heterosexual, marital, monogamous, reproductive, and non-commercial,' is contrasted with the 'outer limits,' usually seen as 'homosexual, unmarried, promiscuous, nonprocreative, or commercial' (Rubin, 1984, pp.280-1). Rubin further suggests that the line between normal and its others is also 
imaginary, contested and shifting. Around the same time Wittig, too, sought to develop a critical approach to heterosexuality, arguing that the ideas of female/male are in fact created via an oppressive social system, in which heterosexuality is taken to be foundational. Her concept of the 'straight mind' is used to suggest that some kind of 'different/other' is necessary to the maintenance of dominance, and therefore that lesbians, gay men and/or feminists should challenge the very sexual and gendered categories used to uphold such rigid, oppressive social relations (Wittig, 1992, p.31).

Queer theorists have developed these ideas further; in particular, via the notion of heteronormativity, which is described by Berlant and Warner as 'the institutions, structures of understanding, and practice orientations that make heterosexuality seem not only coherent - that is, organised as a sexuality - but also privileged' (Berlant \& Warner, 1998, p.548). This concept has enabled queer theory to move beyond a focus only on the experiences of sexual minorities, in order to examine the systems that afford status to certain sexual forms and identities over others, since all kinds of things, not just sexual, are understood as indicating heterosexuality and so become endowed with moral value and status. In contrast, identities, relations and behaviours that are understood as outside of heterosexuality come to be seen as excessively sexual and in need of control or restriction.

\section{Queering social work?}

Much of social work theory and research does not engage with queer theory at all. Mainstream social work texts do not mention it, even where they discuss poststructural, discursive and anti-oppressive theories (Garrett, 2013; Healy, 2014; Payne, 2014), and a 
significant section of the literature on lesbian, gay, bisexual and transgender (LGBT) issues also fails to engage. This applies to LGBT-affirming/affirmative practice, which tends to rely on a community model for sexual minorities and advocates cultural competence, wherein practitioners develop their understanding of LGBT culture and reflect on their own homophobia (Mallon, 1999; Bergh \& Crisp, 2004). These models see no need for any new theory of social work practice, and affirm existing sexual identities as 'normal variation[s] in human sexuality' (Appleby \& Anastas, 1998, p.402).

Perhaps more surprising is the omission of queer from discussions of radical social work. Miles' chapter in Radical Social Work Today, for example, is largely concerned with questions of the prevalence of LGBT communities, homophobia, transphobia and the need for 'friendly environments' (Miles, 2011, p.93), but has little to say about the contingency of sexual and gender categories themselves. In addition, while there is a concern with the role of late capitalism in oppression, there is no analysis of how socio-economic relations might produce limited, even commercial sexual categories. These strands of social work theory, therefore, reinforce rather limited accounts of an LGBT culture, see sexual categories are mere human variation, largely argue for an assimilationist politics, regard homophobic/transphobic issues as individual, psychological problems, and do not concern themselves with the discursive production of sexual knowledge.

Other strands of social work theory appear merely to assimilate queer into otherwise unchanged perspectives. Accounts of queer which stress demands for visibility (Harris \& White, 2013) or sexuality as 'a matter of choice' (Bywater \& Jones, 2007, p.33) are interesting for us because they suggest that much social work literature is only able to make 
sense of queer theory through a liberal rights approach. The literature on anti-oppressive or anti-discriminatory practice tends either to ignore queer or to present it as fitting neatly into existing models, with Thompson mentioning queer, performativity and the influence of Foucault and Butler, but linking these with cultural aspects of his personal-cultural-social model of discrimination (Thompson, 2016). This perspective tends to see sexuality in the realm of attitudes but pays little, if any, attention to the production of sexual knowledge and categories.

However, there is also a range of writing in social work that engages more thoroughly with queer theory. Todd and Coholic state that queer is concerned with three fundamental questions: how we take up sexuality/gender, how these categories come to mean what they do, and what institutional practices give meanings to those categories (Todd \& Coholic, 2015, p.288). They argue Foucault's view of sexuality as a system of knowledge is an important insight for social work, yet they add that this is often a challenging perspective for those in social work who may require the certainty of fixed sexual categories. MacKinnon adds that social work theory which merely challenges homophobic, biphobic and transphobic ideas allows heteronormativity to go unquestioned, and tends to reinforce ideas about sexual types. Queer, instead, has an 'interest in thinking about the way in which social work discourses shape and are shaped by social fantasies of sexual difference' (MacKinnon, 2011, p.141). Further, Poon suggests that, where black, Asian and other queers of colour are mentioned at all, social work theory tends to depict them as stuck in culturally determined practices, so that these may be 'acquired and mastered' via cultural competence (Poon, 2011, p.148). 
Foucault's influence is mentioned by Willis (2007), Brown and Cocker (2011) and Fish (2012), and developed in O'Brien's chapter, which argues that sexual categories are produced through social work, and that the discipline is 'deeply implicated in the construction of power relations in sexuality' (O'Brien, 1999, p.151). This focus on the production of sexual knowledge via social work highlights the ways in which sexuality is frequently treated as an object of expert knowledge. O'Brien points out that social work has often concerned itself with the "... "occurrence" and the "causes" of sexual activities among young people' (O’Brien, 1999, p.134), where these are regarded as objects of concern, or as indicators of dangerous, deviant behaviour. Butler and Sedgwick are also mentioned as key influences by several writers (Willis, 2007; Brown \& Cocker, 2011; Fish, 2012; Schaub et al., 2016), with Butler's work the subject of two chapters by Featherstone and Green, which urge us to keep gender and sexual categories open to 'resignification and contestations' (Featherstone \& Green, 2013, p.70). They argue Butler's insights are necessary to challenge the 'sterile intellectual context of social work where dogma has often ruled in relation to anti-oppressive practice' (Featherstone \& Green, 2013, p.71), and that a belief in theoretical 'innocence' (Green \& Featherstone, 2014, p.32) is demonstrated by anti-oppressive views of language as transparent and straightforward.

Other writers have noted queer's connection to poststructuralism and have suggested that social work give attention to the ways in which it constructs the very sexual or gender categories it may wish to 'empower' (Burdge, 2007; Martinez et al., 2011; Schaub et al., 2016). McPhail, for example, reminds social workers that they should ask how such categories work and whose interests they serve (McPhail, 2004). There are also some criticisms of the application of queer theory to social work, with Mulé suggesting there is a 
'distinct queer culture' (Mulé, 2015, p.18) with 'unique needs' (Mulé, 2008), and describing queer theory as something academic and individualised, which 'does not offer applications for societal change' (Mulé, 2015, p.19). Willis (2007) adds that queer theory is sometimes too abstract, removed from most people's everyday experience, and suggests that LGBT communities play an important role in many lives. However, he also echoes the dangers and homogenising effects in assuming a set of social work needs for all LGBT people.

\section{Post-queer theory?}

Race, empire and the War on Terror:

A key post-queer development has been insistence that 'considerations of empire, race, migration, geography, subaltern communities, activism, and class are central to the continuing critique of queerness, sexuality, sexual subcultures, desire, and recognition' (Eng et al., 2005, p.2). A number of theorists have focused on whiteness, privilege and queer theory (Riggs, 2006) with Barnard (2004) arguing that queer has tended to canonise white writers, drawing upon black theorists whilst failing to qualify them as queer. Barnard argues for a queer theory 'amenable to an understanding of sexual identity as formatively shaped by race' (Barnard, 2004, p.13) rather than one based upon assumed, white commonalities, and for analysis of the ways in which race and sexuality are mutually constituted. Thus, the problem with the position taken by some queer theorists is that establishing a queer critique of heteronormativity does not release the self from power dynamics and might actually enable whiteness to remain unquestioned. This means that some versions of queer politics ignore or avoid racial questions or contribute to white and nationalist imaginaries via processes which construct new racial others. In some versions of queer, the 'non-white' 
person appears only as the victim of imagined oppressive, non-Western, often Muslim, regimes, or the figure of the violent homophobe is constructed as the non-Western, often Muslim, immigrant. A number of commentators highlight problematic descriptions of black or non-Western communities and cultures as more homophobic than others (Snorton, 2014; Haritaworn, 2015) and, crucially, argue that queer theory ought to be concerned with the ways in which such racist discourses are produced and used, in order to avoid their reinforcement.

Puar's work has pointed out that queer activism and theory have developed a dependence upon 'ever-narrowing parameters of white racial privilege, consumption capabilities, gender and kinship normativity, and bodily integrity' (Puar, 2007, p.xii). She has argued that Western terror strategies, including war and immigration policies, have depended upon the creation of new queer subjects such as 'the terrorist' and 'the Muslim homophobe' in order to justify increasingly racist, nationalist discourses. In 'Monster, terrorist, fag,' Puar and Rai (2002) suggest that the figure of the terrorist draws upon notions of perversity - the terrorist as some kind of queer character, based upon failed heterosexuality - and is used to shore up heteronormative patriotism. Thus, Western counter-terrorism 'intelligence' suggests that such violence is the result of non-Western sexual and gender repression, inconsistent mothering, frustrated heterosexuality and 'fantasies of cleanliness' (Puar \& Rai, 2002, p.122). This suggestion of a liberal West - supposedly founded upon women's and gay rights - and a sexually repressed and repressive Muslim East is then used as a justification for imperial projects of war. Butler's later work, too, makes similar observations about the justification of war and the control of immigration via notions of the sexually progressive West, and about the ways in which responses to torture at Abu Ghraib and other locations 
have suggested that, 'for both torturer and tortured, homosexuality represents the destruction of one's being' (Butler, 2009, p.90). She has added that the construction of a 'gay racist/Muslim homophobe' binary ought to be a focus for queer critique, since this relies on the recognition of simplistic subjectivities and does not allow for the possibility of Muslim or anti-racist LGBT persons, for example.

Many of these ideas reflect a concern to question neoliberal, white, national politics and it is here that Duggan's concept, 'homonormativity', becomes relevant. She suggests that there is now a dominant liberal rights agenda within LGBT politics, largely focused on legal reform, which:

does not contest dominant heteronormative assumptions and institutions, but upholds and sustains them, while promising the possibility of a demobilised gay constituency and a privatised, depoliticised gay culture anchored in domesticity and consumption (Duggan, 2003, p.50).

This homonormativity represents an LGBT politics or community that has embraced neoliberal forms of government, in which state welfare and redistributive forms of social policy have shrunk in favour of private business, liberal equality politics and assimilation of LGBT people via capitalist consumption strategies.

Puar has extended this concept, talking instead about 'homonationalism', which draws upon 'sexual exceptionalism' (Puar, 2007, p.2), in which nation states police the sexual and racial other in order to define borders and cultures, but also produce a version of acceptable 
homosexuality, that which accords with the imperial and neoliberal project. In this way, some LGBT persons and projects become complicit with the heterosexual nation state, so that certain homosexualities are made exceptional, incorporated into nationalist discourse. Human rights abuses are figured as outside of the nation state, outside of the Western world, in order to justify war campaigns, a dynamic that some versions of Western feminism may contribute to, via suggestions that Islamic fundamentalism represents the 'single greatest violent threat to women' (Puar, 2007, p.6).

Class, economics and materialism:

While Duggan draws attention to the reactionary objectives of a strand of LGBT politics concerned only with narrow civil rights, other writers argue that queer theory has failed to consider matters of class and economics. Hennessy (2000) identifies how some queer writing has reproduced an atomised understanding of identity politics which lacks the rigour of a Marxist analysis; for instance, she notes how Warner recognises the importance of questions of economics, but then goes on to assert that a class-based analysis is 'useless' for description of the 'group or nongroup that queer people constitute' (Warner, 1993, p.xxiv). Hennessy suggests this is evidence of a problematic conception of class itself: as a subject position or a social structuring system along the same lines as gender or sexuality, rather than an effect of the organisation of labour and the distribution of resources.

Some lesbian and gay studies work had already explored the importance of urbanisation, capitalism and consumer culture for providing the conditions for people to see themselves as part of a wider lesbian and/or gay community, while also producing the heterosexual family as an economic and social unit (D'Emilio, 1983). Hennessy, however, is more 
concerned with the characteristics of sexual identification itself, arguing that the process of identifying as lesbian, gay, heterosexual or any other sexuality occurs through the logic of the commodity, where aspects of a person's self become understood as objects that are owned and can be disposed of, and that such a logic 'binds ways of knowing and forms of identity to changes in the relations of production' (Hennessy, 2000, p.103).

For Hennessy, queer theorists such as Butler provide a deep critique of heterosexuality, but one which is also limited to the extent that it treats heterosexuality as a discursive formation, rather than a social structure that produces a gendered division of labour within hous eholds and enables gendered and racial inequalities to be exploited for profit. However, this view of queer theory as preoccupied with discourse, because of its grounding in Foucault, relies on a flawed characterisation of Foucault's work as simply concerned with discourse as language, rather than with institutions, regulatory processes and relations of power more generally. Still, Hennessy's critical approach provides some important insights; for instance, she observes that the flexible, mobile and unfettered labouring subjects increasingly required by neoliberalism are remarkably like the fluid bodies, identities and desires that appear in some queer writing. These might disrupt some norms but they are unlikely to challenge neoliberalism - in fact they might participate in its mystification - and this discussion chimes with the critique of neoliberal politics developed in queer/crip writing about disability. In particular, McRuer's (2006) and Clare's (2015) explorations of the intersections between queer and disability involve a deeper engagement with local contexts, material spaces and lived bodies than the literature Hennessy discusses, and they are equally critical of simplistic notions of queer fluidity and flexibility. McRuer also draws on D'Emilio's (1983) discussion of the relationship between capitalism and the development 
of a gay community, showing how the atomised, heterosexual familial units produced and required by late capitalism are challenged by queer and disability rights models of living, which have involved reconfiguring 'our ways of relating to and depending on [...] each other' (McRuer, 2006, p.94).

Gender, feminism and anti-normativity:

It is important to remember that most of the texts now regarded as foundational to queer theory were concerned with gender, even though they were critical of some versions of feminist theory. Butler, for example, reminds us that questions of sexual relations cannot be reduced to gender analysis only, but adds that 'it does not follow that an analysis of sexual relations apart from an analysis of gender relations is possible' (Butler, 1997, p.11). For Sedgwick, an emphasis on anti-homophobic over feminist inquiry occurs only because the latter is 'considerably more developed' (Sedgwick, 1990, p.16), and because analysis of sexuality ought not to be reduced to those of gender relations. That being said, queer theory's relations with gender politics and feminism have been the subject of much debate and reassessment. Martin, for example, is weary of queer, anti-normative critiques that see 'feminism itself as the anti-sexual, identificatory muck out of which any good queer must pull him- or herself' (Martin, 1996, p.10). Other feminists have criticised queer writing that ignores gendered discourses - Jackson, for example, has pointed out that any critique of heterosexuality must consider both heteronormativity and gender hierarchies, adding that 'institutionalised, normative heterosexuality regulates those kept within its boundaries as well as marginalising and sanctioning those outside them. The term "heteronormativity" has not always captured this double-sided social regulation' (Jackson, 2006, p.105). Jagose (2009) also reminds us that much of feminist theory has concerned itself with the 
problematic category 'women', and that feminism has been a key site for the investigation and, frequently, promotion of its instability - ironically a rather queer concept.

This debate also relates to questions of anti-normativity, with the normative/anti-normative being one of the key points for the reassessment of queer. For example, it is possible to argue that queer theory has sometimes been presented as rebellious and transgressive, as though all LGBT and queer persons were merely able to step outside of racial, gender or sexual norms, and as though queer were somehow automatically more transgressive than other ways of thinking about sexuality politics. Wilson's piece, 'Is transgression transgressive?' (Wilson, 1993), however, argues that, because socialist ideas have disappeared from much of lesbian and gay politics, claims to transgression are often all that remain. Yet, she notes, a politics of opposition and subversion may simply reinforce some conventional ideas, since transgression relies upon these in order to react against them. While she does not reject transgression's importance, Wilson reminds us that this is often a tactic rather than a politics. Wiegman has made similar arguments, specifically regarding queer theory, and has suggested that:

with antinormativity as the highest critical value, ... [queer] must cultivate, often to the point of idealisation, the most resolutely alternative - that is, the most radically perverse and socially unassimilable - in order to do justice to the project of alterity and difference invested in the sign of the queer (Wiegman, 2012, p.339). 
Wiegman and Wilson's special edition of differences (2015) does not argue for disengagement with the normative but does ask what might happen if the anti-normative were not queer's main focus. They ask this because anti-normative stances tend to 'reduce the intricate dynamics of norms to a set of rules and coercions' (Wiegman \& Wilson, 2015, p.13). Heteronormativity, however, is not some kind of agent that coerces individuals, it is rather produced via social interactions or the negotiation with norms that all people must contend with and it is, too, a product of queer thinking. This point is an important sociological one, since a concern regarding queer theory has been its tendency, in some cases, to present over-determined, overly-textual accounts, in which people's lives appear to be dictated by norms, rather than those norms actually arising through forms of interaction between persons and institutions. Heterosexuality, for example, is much more complex and contradictory than some analyses of the heteronormative seem to imply.

Thus, the norm/anti-norm binary presented in some queer theory is simplistic and, at times, rather too self-assured. However, ironically, one of the reasons for queer's elisions may in fact be a lack of reflexivity concerning an avowed transgressive stance, since antinormativity is sometimes so defiantly and resolutely taken up that the repetition of norms concerning race, gender, academic discourse, and so on, may meanwhile be reiterated. And, while both Duggan (2015) and Halberstam (2015) have pointed out that queer theory has moved on from such a position and that no single approach to the idea of norms now features in the diverse range of queer approaches, Halberstam's suggestion that, 'abandon antinormativity and you slip quickly into acquiescence' (Halberstam, 2015), does seem to represent the rather self-assured antinormativity that is being questioned. 


\section{What might social work do with post-queer theory?}

The concept of homonormativity is highly relevant for social work, but social work literature has, by and large, yet to engage with the idea, or develop a critical take on its significance for current neoliberal social and economic policy. This is important because claims of increased lesbian and gay equality in social work seem to us frequently to be characterised by homonormativity. As one of us has argued in relation to adoption (Hicks, 2011), lesbians and gay men have been valued by social workers to the extent that they perform homonormative relationships, which leads us to question whether practice challenges narrow versions of 'family' and accepts a broad range of relationalities, or whether some lesbians and gay men are now being included within a notion of the normative that is substantially unchanged. Social work discussions also need to consider the potential relationship between a turn towards homonormativity in certain areas of social work and practices which are potentially increasingly problematic in terms of race, gender and class. For example, the recent surge in gay adoption in Britain has been enabled by policy developments that have been criticised in such terms. Some of these matters have been considered in the recent, reinvigorated discussions about class, economics and the production of moral subjects in social work (Featherstone et al., 2014). We see the potential of queer writing here to enable insights about how various groups of people, most of whom are not lesbian, gay, bisexual or transgender but are marginalised in terms of class, race or location, come to be positioned in social work as problematic in sexual, as well as moral, terms. 
Discussions of sexuality in equality and diversity or anti-discriminatory practice literature have often presented LGBT equality as a question of the inclusion of a broader range of relationships into notions of normality. Within this, positive representations and greater visibility have frequently been presented as solutions to the perceived problem of heterosexist or homophobic attitudes (Thompson, 2016). Queer theory has, from its beginnings, been highly sceptical about the promotion of norms or the benefits of positive representation. Bearing this in mind, social workers would do well to imagine ways of combatting stigma, shame and hierarchies of value in ways that do not impose new norms or reproduce narrow representations of matters such as sexual practices, dignity in personal assistance and relations of care and love more generally.

Post-queer theory's engagement with race and the homonational also offers social work the opportunity to ask some critical questions about its own thinking in these areas. Much of the writing on social work and race does not address sexuality at all, and anti-racist social work theory also tends to reject the postmodern as incapable of dealing with socioeconomic concerns or producing any kind of agenda for political change (Lavalette \& Penketh, 2014; Singh, 2014). However, in a context in which the sexual abuse of young women in British towns and cities has been explained through notions of 'street-grooming gangs', and in which South Asian men are represented as both 'culturally' more likely to commit sexual offences and essentially interchangeable, the suggestion that social workers are unable to speak out for fear of being labelled 'racist' actually masks what are heavily racialised, gendered and class-infused discourses. Turney, for example, suggests that a text such as Anti-Racist Social Work (Dominelli, 1988) treats the language of race as an 'essentially transparent medium', in which racism may be easily eradicated from both 
speech and, thereby, social relations (Turney, 1996, p.8). For Turney, however, deconstruction theory proposes not that racism is simply removed from speech/actions by the individual, but rather that race is produced through discourse and is, in this sense, a 'linguistic resource' (Turney, 1996, p.16) used in many social work accounts, which is important for analysis of the kinds of understandings of race and 'the racial other' that social work produces.

Finally, Warner has argued that 'queer theory now has the shape of a searching and still largely undigested conversation, rich enough to have many branches, some different enough to be incommensurate with one another' (Warner, 2012) and, on this point, we think that queer and post-queer perspectives might also be used to invigorate social work theory and, indeed, social work's relationship to theory. By this, we do not mean that queer/post-queer should simply be added to yet another list of established social work theories, for this would be in danger merely of qualifying or adding into an otherwise established academic discourse. Instead, we think that, where social work is imagined to 'have been allowed to provide too much theory, too much sociology' (Narey, 2014, p.30), or where postmodern theory is described as 'emasculating' (Gray \& Webb, 2013, p.218) something that sounds queerly attractive - then the need to ask which knowledge forms count as social work theory and which do not is of pressing concern. A genealogy of social work theory concerning sexuality is a necessary project, as is Butler's call for 'inquiry on the production of difference' (Butler, 2011, p.21), if we are to avoid mere description of current sexual categories of persons and their implied social welfare needs, and if we are to encourage a queerer understanding of what counts as sexual knowledge for practice, theory and research. 


\section{References:}

Appleby, G.A. \& Anastas, J.W. (1998) Not Just a Passing Phase: Social Work with Gay, Lesbian, and Bisexual People, New York, Columbia University Press.

Barnard, I. (2004) Queer Race: Cultural Interventions in the Racial Politics of Queer Theory, New York, Peter Lang.

Bergh, N. Van Den \& Crisp, C. (2004) 'Defining culturally competent practice with sexual minorities: Implications for social work education and practice', Journal of Social Work Education, 40(2), pp. 221-238.

Berlant, L. \& Warner, M. (1998) 'Sex in public', Critical Inquiry, 24(2), pp. 547-566.

Brown, H.C. \& Cocker, C. (2011) Social Work with Lesbians and Gay Men, London, Sage.

Burdge, B.J. (2007) 'Bending gender, ending gender: Theoretical foundations for social work practice with the transgender community', Social Work, 52(3), pp. 243-250.

Butler, J. (1988) 'Performative acts and gender constitution: An essay in phenomenology and feminist theory', Theatre Journal, 40(4), pp. 519-531.

Butler, J. (1990) Gender Trouble: Feminism and the Subversion of Identity, New York, Routledge.

Butler, J. (1997) 'Against proper objects', in Weed, E. \& Schor, N. (eds), Feminism Meets Queer Theory, Bloomington, Indiana University Press.

Butler, J. (2009) Frames of War: When Is Life Grievable? London, Verso.

Butler, J. (2011) 'Speaking up, talking back: Joan Scott's critical feminism', in Butler, J. \& Weed, E. (eds), The Question of Gender: Joan W. Scott's Critical Feminism, Bloomington, Indiana University Press.

Bywater, J. \& Jones, R. (2007) Sexuality and Social Work, Exeter, Learning Matters.

Clare, E. (2015) Exile and Pride: Disability, Queerness, and Liberation 2nd ed., Durham, Duke 
University Press.

Cohen, C. (1997) 'Punks, bulldaggers, and welfare queens: The radical potential of queer politics?' GLQ, 3(4), pp. 437-465.

de Lauretis, T. (1991) 'Queer theory. Lesbian and gay sexualities: An introduction', Differences, 3(3), pp. iii-xviii.

D’Emilio, J. (1983) 'Capitalism and gay identity', in Snitow, A., Stansell, C. \& Thompson, S. (eds), Powers of Desire: The Politics of Sexuality, New York, Monthly Review Press. Dominelli, L. (1988) Anti-racist Social Work: A Challenge for White Practitioners and Educators, Basingstoke, Palgrave Macmillan.

Duggan, L. (2003) The Twilight of Equality? Neoliberalism, Cultural Politics, and the Attack on Democracy, Boston, Beacon Press.

Duggan, L. (2015) 'Queer complacency without empire', Bully Bloggers, Available at: https://bullybloggers.wordpress.com/2015/09/22/queer-complacency-withoutempire/, Accessed September 23, 2015.

Ehlers, N. (2012) Racial Imperatives: Discipline, Performativity, and Struggles Against Subjection, Bloomington, Indiana University Press.

Eng, D.L., Halberstam, J. \& Munoz, J.E. (2005) 'What's queer about queer studies now?' Social Text, 23(3/4), pp. 1-17.

Featherstone, B. \& Green, L. (2013) 'Judith Butler', in Gray, M. \& Webb, S.A. (eds), Social Work Theories and Methods, London, Sage.

Featherstone, B., White, S. \& Morris, K. (2014) Re-Imagining Child Protection: Towards Humane Social Work with Families, Bristol, Policy Press.

Fish, J. (2012) Social Work and Lesbian, Gay, Bisexual and Trans People: Making a Difference, Bristol, Policy Press. 
Foucault, M. (1990) The History of Sexuality, Volume 1: An Introduction, London, Penguin.

Garrett, P.M. (2013) Social Work and Social Theory: Making Connections, Bristol, Policy Press.

Gray, M. \& Webb, S.A. (2013) 'The speculative left and new politics of social work', in Gray, M. \& Webb, S.A. (eds), The New Politics of Social Work, Basingstoke, Palgrave Macmillan.

Green, L. \& Featherstone, B. (2014) 'Judith Butler, power and social work', in Cocker C. \& Hafford-Letchfield, T. (eds), Rethinking Anti-Discriminatory and Anti-Oppressive Theories for Social Work Practice, Basingstoke, Palgrave Macmillan.

Halberstam, J. (2015) 'Straight eye for the queer theorist - A review of "Queer Theory Without Antinormativity"', Bully Bloggers, Available at:

https://bullybloggers.wordpress.com/2015/09/12/straight-eye-for-the-queer-theorista-review-of-queer-theory-without-antinormativity-by-jack-halberstam/, Accessed September 12, 2015.

Halperin, D.M. (1995) Saint Foucault: Towards a Gay Hagiography, New York, Oxford University Press.

Haritaworn, J. (2015) Queer Lovers and Hateful Others: Regenerating Violent Times and Places, London, Pluto Press.

Harris, J. \& White, V. (2013) A Dictionary of Social Work and Social Care, Oxford, Oxford University Press.

Healy, K. (2014) Social Work Theories in Context: Creating Frameworks for Practice 2nd ed., Basingstoke, Palgrave Macmillan.

Hennessy, R. (2000) Profit and Pleasure: Sexual Identities in Late Capitalism, New York, Routledge. 
Hicks, S. (2011) Lesbian, Gay and Queer Parenting: Families, Intimacies, Genealogies, Basingstoke: Palgrave Macmillan.

Jackson, S. (2006) 'Gender, sexuality and heterosexuality: The complexity (and limits) of heteronormativity', Feminist Theory, 7(1), pp. 105-121.

Jagose, A. (2009) 'Feminism's queer theory', Feminism \& Psychology, 19(2), pp. 157-174.

Lavalette, M. \& Penketh, L. (2014) 'Race, racism and social work', in Lavalette, M. \&

Penketh, L. (eds), Race, Racism and Social Work: Contemporary Issues and Debates, Bristol, Policy Press.

Mackinnon, K.V.R. (2011) 'Thinking about queer theory in social work education: A

pedagogical (in)query', Canadian Social Work Review, 28(1), pp. 139-144.

Mallon, G.P. (1999) Let's Get This Straight: A Gay- and Lesbian-Affirming Approach to Child Welfare, New York, Columbia University Press.

Martin, B. (1996) Femininity Played Straight: The Significance of Being Lesbian, New York, Routledge.

Martinez, P., Barsky, A. \& Singleton, S. (2011) 'Exploring queer consciousness among social workers', Journal of Gay \& Lesbian Social Services, 23(2), pp. 296-315.

McPhail, B.A. (2004) 'Questioning gender and sexuality binaries: What queer theorists, transgendered individuals, and sex researchers can teach social work', Journal of Gay \& Lesbian Social Services, 17(1), pp. 3-21.

McRuer, R. (2006) Crip Theory: Cultural Signs of Queerness and Disability, New York, New York University Press.

Miles, L. (2011) 'LGBT oppression, sexualities and radical social work today', in Lavalette, M. (ed), Radical Social Work Today: Social Work at the Crossroads, Bristol, Policy Press. Mulé, N.J. (2008) 'Demarcating gender and sexual diversity on the structural landscape of 
social work', Critical Social Work, 9(1), Available at:

http://www1.uwindsor.ca/criticalsocialwork/demarcating-gender-and-sexual-diversityon-the-structural-landscape-of-social-work , Accessed March 3, 2016.

Mulé, N.J. (2015) 'The politicized queer, the informed social worker: Dis/re-ordering the social order', in O'Neill, B.J., Swan, T.A, \& Mulé, N.J. (eds), LGBTQ People and Social Work: Intersectional Perspectives, Toronto, Canadian Scholars' Press.

Narey, M. (2014) Making the Education of Social Workers Consistently Effective: Report of Sir Martin Narey's Independent Review of the Education of Children's Social Workers, London, Department for Education.

O’Brien, C.-A. (1999) 'Contested territory: Sexualities and social work', in Chambon, A.S., Irving, A. \& Epstein, L. (eds), Reading Foucault for Social Work, New York, Columbia University Press.

Payne, M. (2014) Modern Social Work Theory 4th ed., Basingstoke, Palgrave Macmillan. Penney, J. (2014) After Queer Theory: The Limits of Sexual Politics, London, Pluto Press. Poon, M.K.-L. (2011) 'Writing the racialized queer bodies: Race and sexuality in social work', Canadian Social Work Review, 28(1), pp. 145-150.

Puar, J.K. (2007) Terrorist Assemblages: Homonationalism in Queer Times, Durham, Duke University Press.

Puar, J.K. \& Rai, A. (2002) 'Monster, terrorist, fag: The war on terrorism and the production of docile patriots', Social Text, 20(3), pp. 117-148.

Riggs, D.W. (2006) Priscilla (White) Queen of the Desert: Queer Rights/Race Privilege, New York, Peter Lang.

Rubin, G. (1984) 'Thinking sex: Notes for a radical theory of the politics of sexuality', in Vance, C.S. (ed), Pleasure and Danger: Exploring Female Sexuality, London, Routledge 


\section{\& Kegan Paul.}

Ruffolo, D.V. (2009) Post-queer Politics, Farnham, Ashgate.

Schaub, J., Willis, P. \& Dunk-West, P. (2016) ‘Accounting for self, sex and sexuality in UK social workers' knowledge base: Findings from an exploratory study', British Journal of Social Work, Advance Access published March 22, 2016, doi:10.1093/bjsw/bcw015.

Sedgwick, E.K. (1990) Epistemology of the Closet, London, Penguin.

Singh, G. (2014) 'Rethinking anti-racist social work in a neoliberal age', in Lavalette, M. \& Penketh, L. (eds), Race, Racism and Social Work: Contemporary Issues and Debates, Bristol, Policy Press.

Snorton, C.R. (2014) Nobody is Supposed to Know: Black Sexuality on the Down Low, Minneapolis, University of Minnesota Press.

Thompson, N. (2016) Anti-discriminatory Practice: Equality, Diversity and Social Justice 6th ed., London, Palgrave.

Todd, S. \& Coholic, D. (2015) 'Christian fundamentalism and anti-oppressive practice social work pedagogy: Rethinking the inclusion of fundamentalist beliefs within the queerpositive classroom', in O’Neill, B.J., Swan, T.A. \& Mulé, N.J. (eds), LGBTQ People and Social Work: Intersectional Perspectives, Toronto, Canadian Scholars' Press.

Turney, D. (1996) The language of anti-racism in social work: Towards a deconstructive reading, London, Goldsmiths College, University of London, Centre for Urban \& Community Research: Occasional papers.

Warner, M. (1993) 'Introduction', in Warner, M. (ed), Fear of a Queer Planet: Queer Politics and Social Theory, Minneapolis, University of Minnesota Press.

Warner, M. (2012) 'Queer and then?', The Chronicle Review, 1st January, Available at: http://chronicle.com/article/QueerThen-/130161/, Accessed March 11, 2016. 
Wiegman, R. (2012) Object Lessons, Durham, Duke University Press.

Wiegman, R. \& Wilson, E.A. (2015) 'Introduction: Antinormativity's queer conventions', Differences, 26(1), pp. 1-25.

Willis, P. (2007) “"Queer eye” for social work: Rethinking pedagogy and practice with samesex attracted young people', Australian Social Work, 60(2), pp. 181-196.

Wilson, E. (1993) 'Is transgression transgressive?' in Bristow, J. \& Wilson, A.R. (eds), Activating Theory: Lesbian, Gay, Bisexual Politics, London, Lawrence \& Wishart. Wittig, M. (1992) The Straight Mind and Other Essays, Boston, Beacon Press. 